\title{
RIN2 syndrome
}

INSERM

\section{Source}

INSERM. (1999). Orphanet: an online rare disease and orphan drug data base. RIN2 syndrome. ORPHA:217335

RIN2 syndrome, formerly known as macrocephaly, alopecia, cutis laxa and scoliosis (MACS) syndrome, is a very rare inherited connective tissue disorder characterized by macrocephaly, sparse scalp hair, soft-redundant and hyperextensible skin, joint hypermobility, and scoliosis. Patients have progressive facial coarsening with downslanted palpebral fissures, upper eyelid fullness/infraorbital folds, thick/everted vermillion, ging ival overg rowth and abnormal position of the teeth. Rarer manifestations such as abnormal high-pitched voice, bronchiectasis, hypergonadotropic hypergonadism and brachydactyly (see this term) have also been reported. 